\title{
Are corestones due to weathering and/or tectonism? Problems and suggestions
}

\section{Los bolos residuales ¿se deben a la meteorización o a la tectónica? Problemas y sugerencias}

\author{
CHARLES ROWLAND TWIDALE ${ }^{1}$ AND JUAN RAMÓN VIDAL-ROMANI' ${ }^{* 2}$ \\ ${ }^{1}$ Department of Geology and Geophysics, School of Physical and Earth Sciences, University of Adelaide \\ ${ }^{2}$ Instituto Universitario de Xeoloxía, Universidade da Coruña. ESCI, Campus de Elviña. 15071, A \\ Coruña, Galicia, Spain. \\ *Autor de contacto: juan.vidal.romani@udc.es
}

https://doi.org/10.17979/10.17979/cadlaxe.2020.42.0.7268

Recibido: 16/06/2020, Aceptado: 28/06/2020

\begin{abstract}
:
Many of the so-called corestones have been developed from rocky blocks that have been apparently affected by subsurface physicochemical weathering that results in lamination, granulation, and eventually a puggy or stiff clay. The truth is that weathering takes advantage of a previous deformation structure and does not create it by weathering.
\end{abstract}

Key words: granitic geomorphology, weathering processes, blocks, shearing, residual cores 


\section{Resumen:}

Muchas de los llamados bolos residuales se han desarrollado a partir de bloques rocosos que han sido aparentemente afectados por la meteorización fisicoquímica del subsuelo que da lugar a la laminación, la granulación y, finalmente, a una arcilla rugosa o rígida. Lo cierto es que el desgaste aprovecha una estructura de deformación previa y no la crea por meteorización.

Palabras clave: geomorfología granítica, procesos de meteorización, bloques, cizallamiento, núcleos residuales 


\section{INTRODUCTION}

Travelling in the southern Massif Central of France, in the vicinity of Aumont late in the Eighteenth Century. J.-H Hassenfratz (1791 p. 101) observed 'floaters' or rounded boulders of granite, set in a matrix of rotten rock that he related to the boulders exposed at the surface (Figure 1). Hassenfratz thought that some granite boulders was generated by abrasion in flowing streams and in the surf zones of coastal sectors, but, many, and perhaps most, corestone boulders -the name originated with Scrivenor (1913)- but others thought were shaped apparently by differential weathering in the subsurface and exposed as the friable matrix is evacuated under gravity or by wash. This finding was reported by Hutton (1788) and similar occurrences, though in a variety of climatic, lithological and chronological environments and contexts, were reported from various parts of the World.

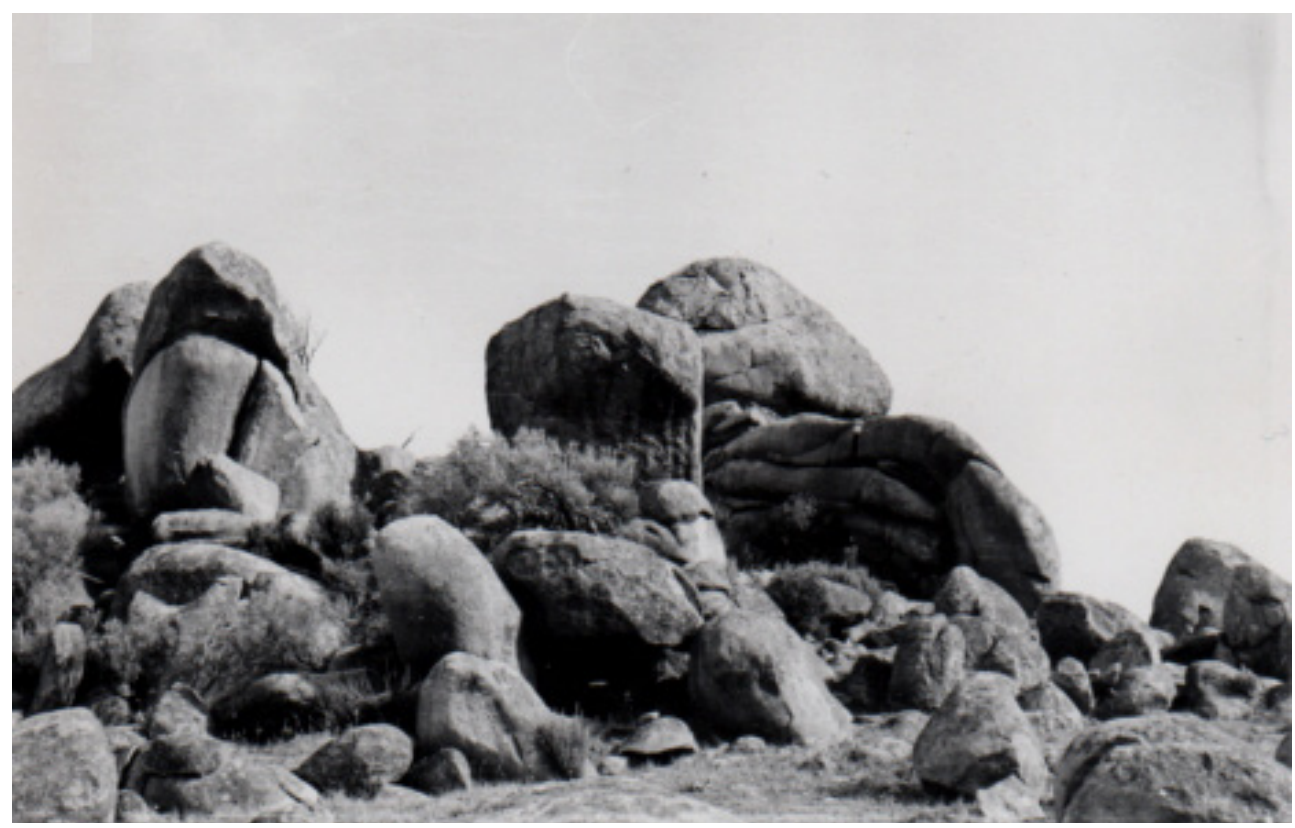

Figure 1. Granite boulders and partly exposed corestones, southern Massif Central, France

More or less rounded corestone boulders are typical of granite exposures but are also well developed in other igneous rocks such as dolerite and norite, in rocks that like granite are characterized by well-developed systems of orthogonal fractures defining parallelepiped blocks (Figure 2). They are also developed, though less commonly, in sediments such as sandstone and quartzite, and Hassenfratz (1791 p.105) himself also noted, northeast of Toulouse, corestones in limestone that were though less well defined than their counterparts in granite, nevertheless two stage corestones (Figure $3 \mathrm{a}$ and $3 \mathrm{~b}$ ). 


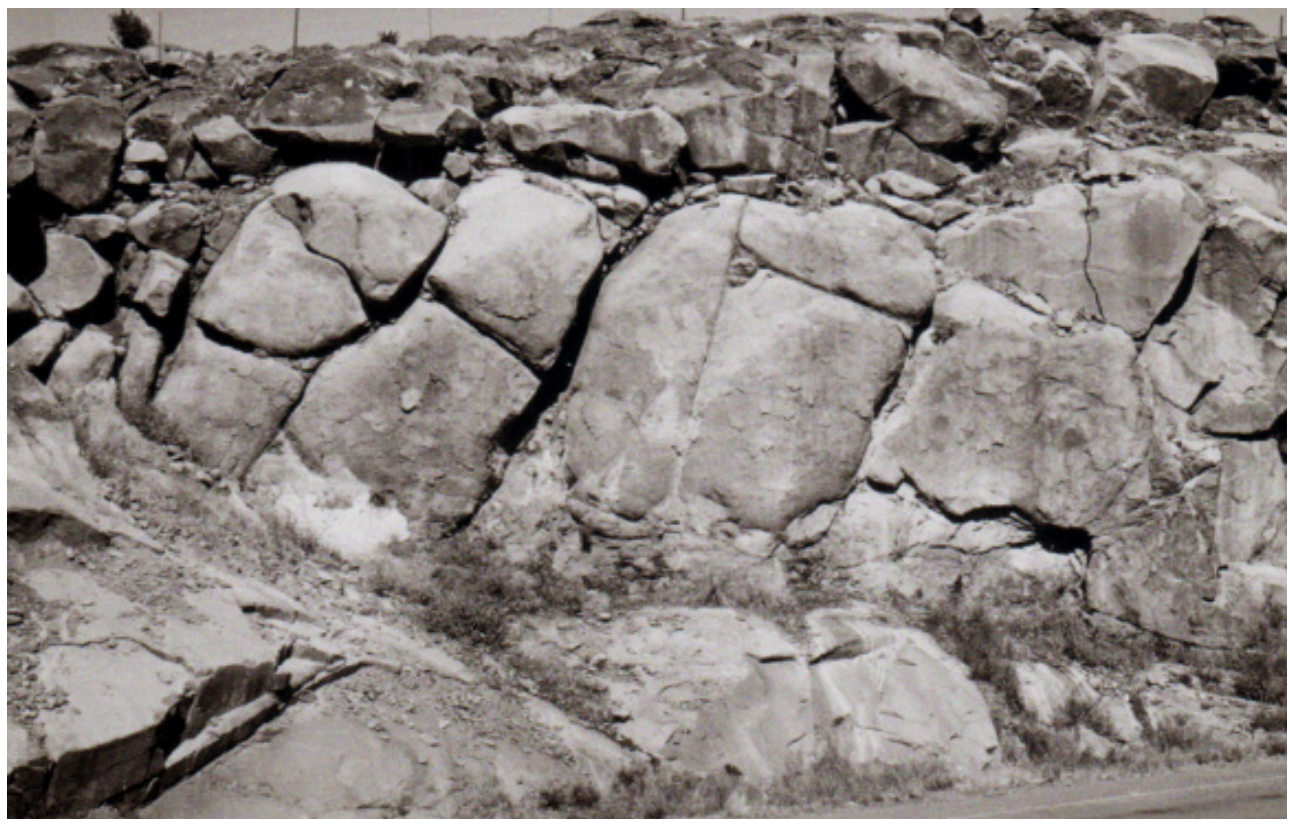

Figure 2. Orthogonal jointing exposed in Blackingstone quarry, eastern Dartmoor, southwest England,

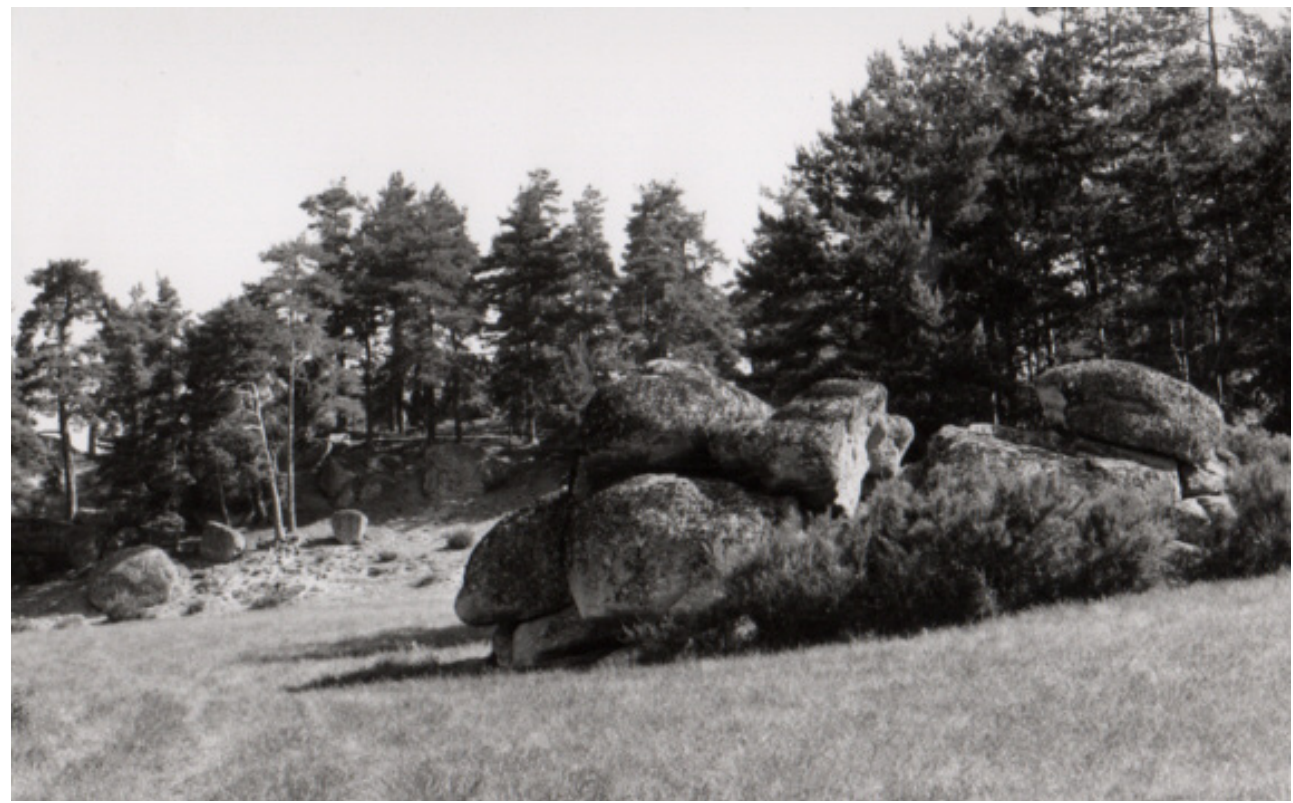

Figure 3. (a) Corestones in sandstone exposed in road cutting in Pichi Richi Pass, between Port Augusta and Quorn in the southern Flinders Ranges. 
Several workers erroneously appreciated that the conversion of angular blocks to rounded corestone boulders was due to the preferential weathering of the corners and edges of the initial forms that were exposed to moisture-based attack on two or three sides by contrast with a plane face that is exposed on only one. But although this is true in some cases, in most of them it is the tectonic structure due to the intrusion of the granite, which causes the structure that is later used by the weathering process.

A sphere is the form with the greatest volume per surface area and is also the most stable, or the least vulnerable to preferential weathering and hence erosion (eg MacCulloch, 1814; de la Beche, 1839, 1853; Logan, 1849 , p. 24; 1851 pp 327-328; Jones, 1859. And hence the idea that the spherical forms presented by the rocky blocks are the final members of a series consequence of the continued weathering of the rock. That the rounded corestones are in situ and were not abraded during transport was demonstrated by Kingsmill (1862) and others who noted intrusive veins in situ among the weathered blocks (e.g. Figure 4). Moreover, once exposed, the boulders are relatively stable for, as Logan (1851, p. 325) pointed out, they are no longer in perpetual contact with moisture, the major agent of mineral alteration, and tend to retain their rounded form. By contrast gneisses and schists with a well-developed cleavage give rise to penitent rocks (monkstones, tombstones -e.g. composition of the country rock) (Figure 5). But in general terms they comprise a mixture of chemical and physical changes (hence 'physicochemical').

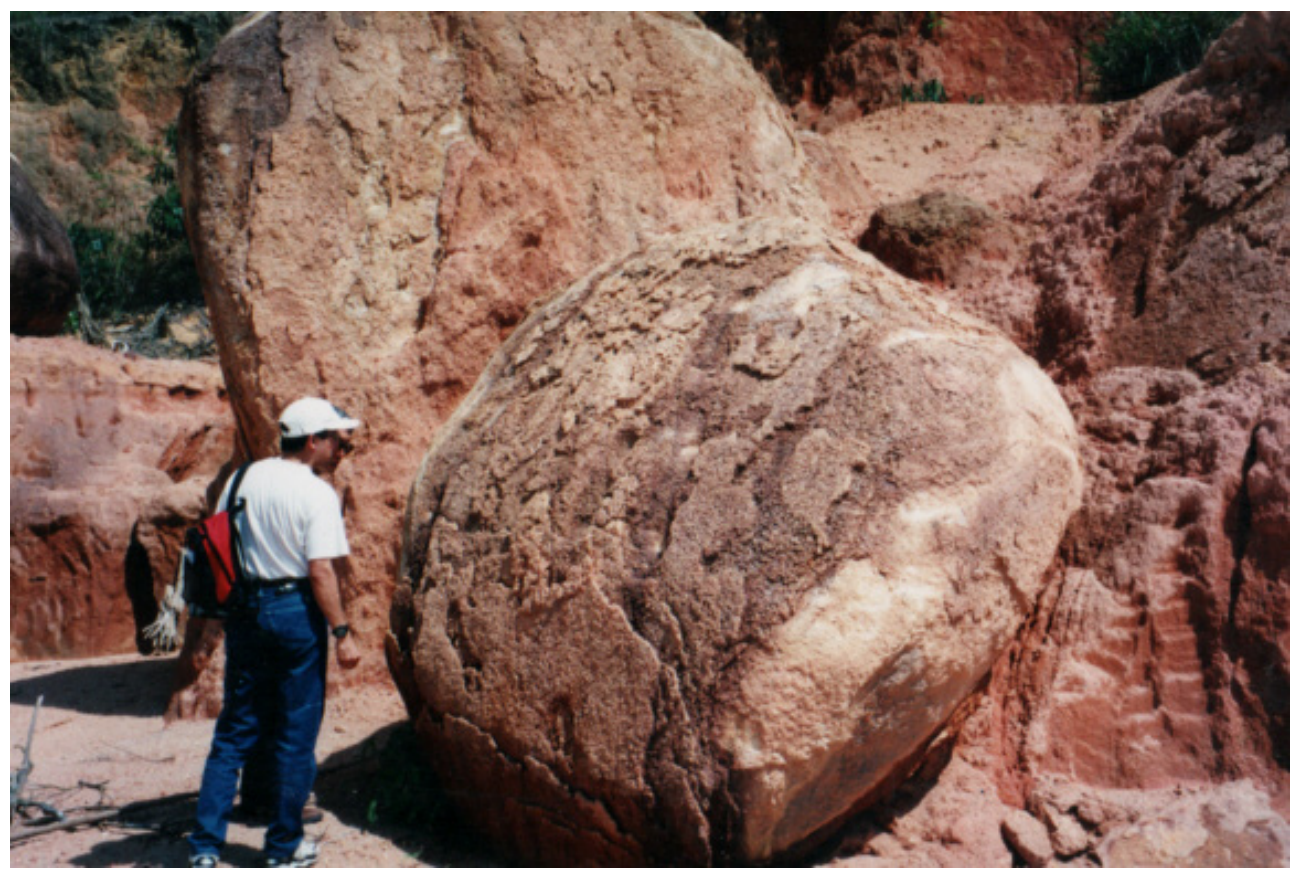

Figure 3.(b) Potential corestones in marble outlined on exposed face of quarry at Chillagoe, Cape Yorke Peninsula, north Queensland. 


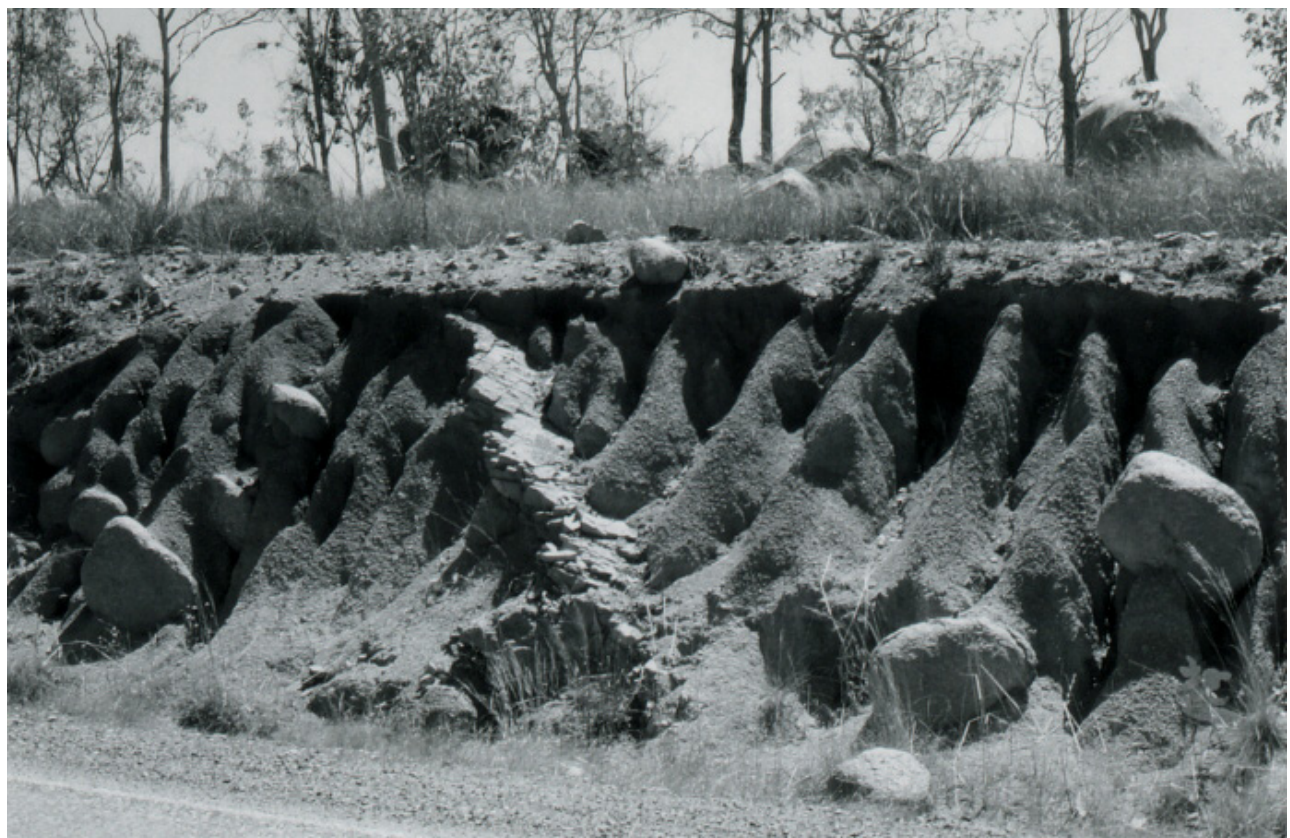

Figure 4. Road cutting in Rocky Mountains, Colorado, with weathered corestones and exposed corestone boulders. Intrusion shows that the granite forms are in situ and not transported.

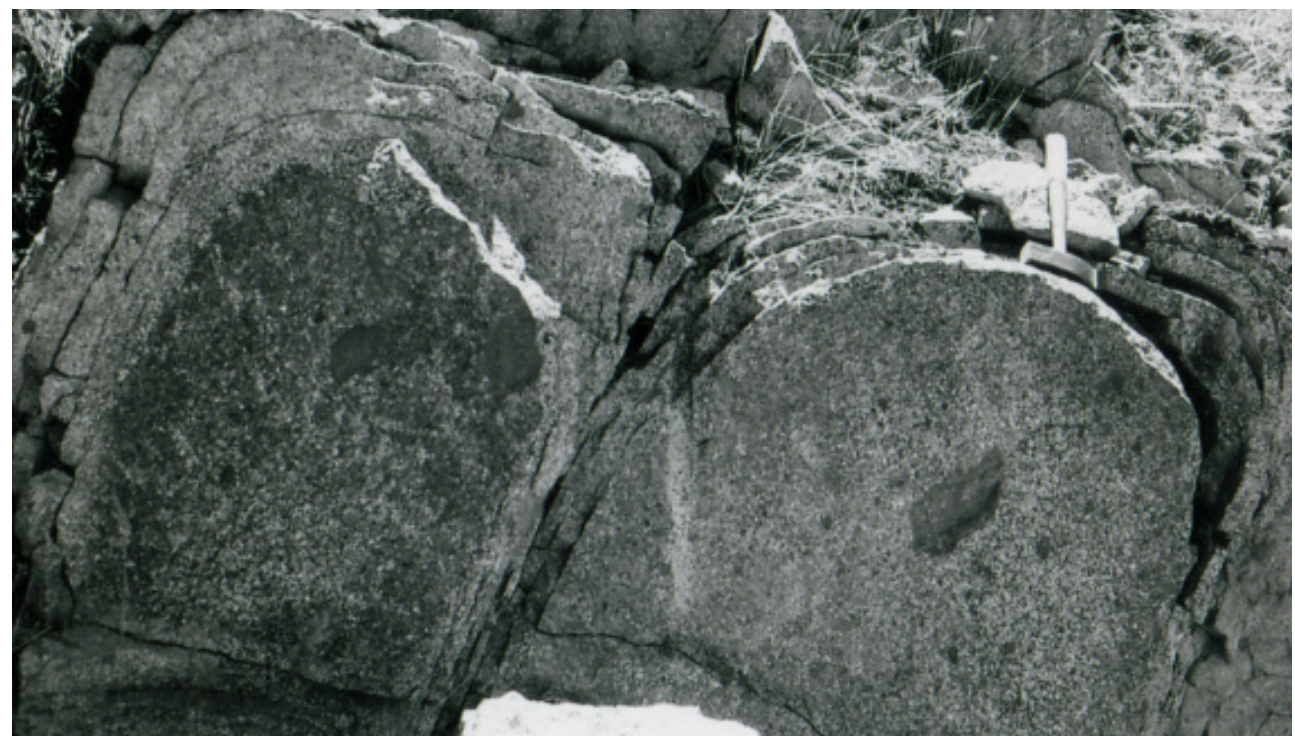

Figure 5. Penitent or tombstone rocks, Tungkillo area, $18 \mathrm{~km}$ west of Palmer, eastern Mt Lofty Ranges, South Australia. 
This is well illustrated in a profile exposed in the Yarwondutta granite quarry (see map in figure 6), $4 \mathrm{~km}$ north of Minnipa, on north western Eyre Peninsula (Twidale 1986, (). The sequence of alteration and consequent morphological change (Figure 7) is recorded in the regolith (e.g.
MacCulloch, 1814). The nature of initial alteration is found at and near the weathering front, or Tiefenfront, located at the base of the regolith (Büdel, 1957; Mabbutt, 1961). The nature and order of subsequent developments can be traced in sequence from the base to the top of the regolith.

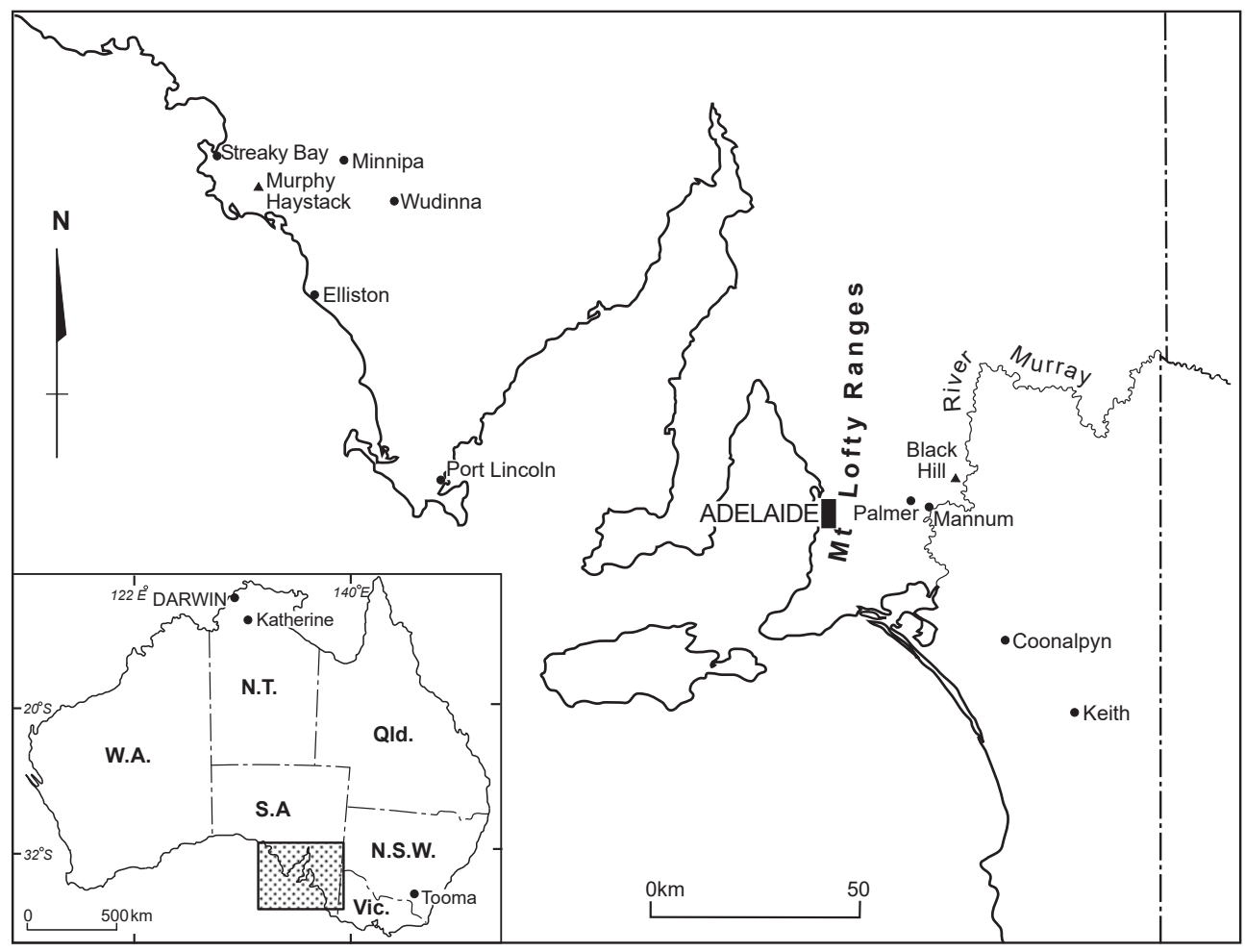

Figure 6. Location map (Australia) 


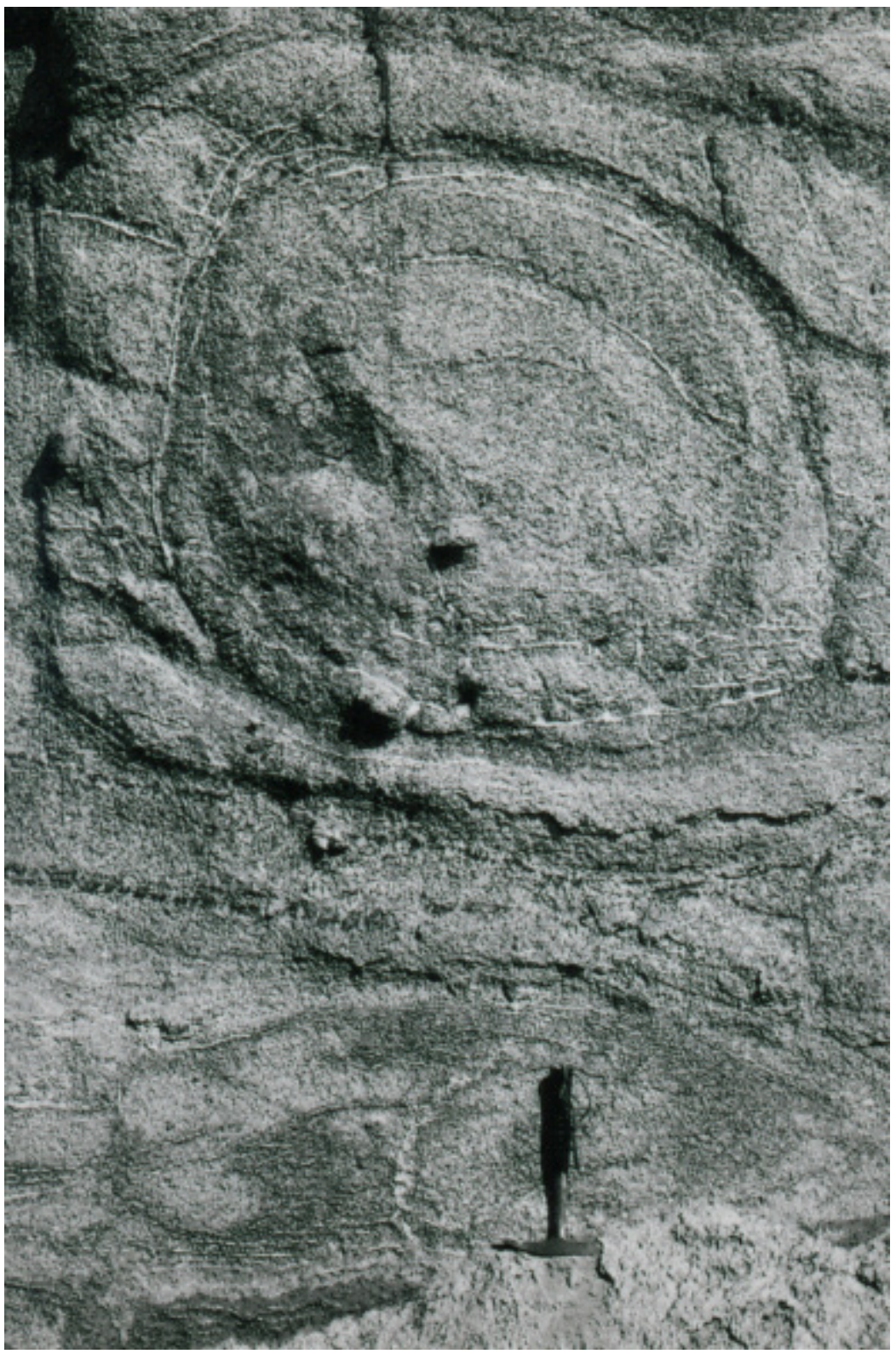

Figure 7. Section of weathered granite exposed in Yarwondutta Quarry, $4 \mathrm{~km}$ north of Minnipa, NW Eyre Peninsula, South Australia. The hammer rests on the zone of calcareous impregnation and the surface cobbles are of calcrete. The basal zone (L) resting on the fresh bedrock is laminated and ferruginous. Grus occupies most of the section and the ratio of clay to unweathered rock-forming minerals decreases up the profile. Even the quartz is rare in the higher horizons. 
The profile is complex in that it bears the imprint of two environments, one humid and the later semiarid, The initial change in granite is due to the infiltration of water along fractures and the alteration the rock with which it comes into contact. Quartz and larger feldspar crystals remain virtually unaffected, but mica and most feldspars are hydrated and become clays. Some clays produced by the weathering of micas and feldspars are hydrophilic (Loughnan 1969, p. 69) and swell on further contact with water, physically disrupting the rock and creating slivers that together produce a laminated texture. This induces a reinforcement effect in that it permits readier water access to the rock. The nature of the clay varies with original mineral composition and the nature of drainage (Larsen, 1948; Eggler et al., 1969; Loughnan, 1969). For example, the weathering of norite from Black Hill, an early Paleozoic inlier located in the western Murray Basin (see map in figure 6). produces nontronite, a yellow iron-rich montmorillinitic mineral (Hutton et al., 1977). All except the larger feldspars and quartz are altered and the weathered matrix is dominated by clay and quartz fragments. Eventually even the quartz is dissolved. Thus, the amounts of feldspar and quartz in the regolith decrease up the profile whereas clay becomes more and more prominent. lron oxide (haematite, goethite) released by the weathering of mica and any other ferromagnesian minerals is illuviated and is concentrated at the base of the regolith, against the impermeable fresh granite. and even a few centimetres within the fresh country rock (though this last may reflect access along fissures within the still unexposed rock mass). But the end-products of granite weathering are first a grave or grus, and later a puggy or stiff clay (S. M. Kraemers, pers. comm. 1983). Superimposed on this sequence however is wind borne carbonate dust derived from the break down of calcarenitic dunes deposited along the entire west coast of Eyre Península during the Middle and Late Pleistocene (Wilson 1991, Belperio 1995; Milnes and Ludbrook 1986). The dust settled on the surface of the weathered granite and there formed what has become a massive, but now broken, crust, Dust was also was illuviated into the weathered mantle where is decreases in prominence down the profile.

\section{VARIATIONS IN WEATHERING AS EXEMPLIFIED BY THE PALMER GRANITE}

Various stages in the development of corestones can be recognised. Sorne are barrel -shaped or spheroidal with the bedrock kernels flanked by tetrahedra and thin slabs or plates of fresh country rock, Others are set in a matrix of laminated rock, some by grus, and yet others by arcuate plates. Possible reasons for the most common weathering patterns are suggested by their distribution on the Early Palaeozoic Palmer granite stock, which is lenticular in plan shape, some $5 \mathrm{~km}$ north south, and 1.5 $\mathrm{km}$ east-west, and is exposed in the eastern Mt Lofty Ranges, adjacent to the fault zone that delimits the horst on the eastern side, and some $50 \mathrm{~km}$ east of Adelaide (see map in Figure 6). The outcrop is dissected, with boulder strewn crests (Figure 8 ) and smooth sandy lower slopes leading down to valley floors and basins in which severa! metres of sediments (including boulders and pieces of barbed wire) have been deposited. 


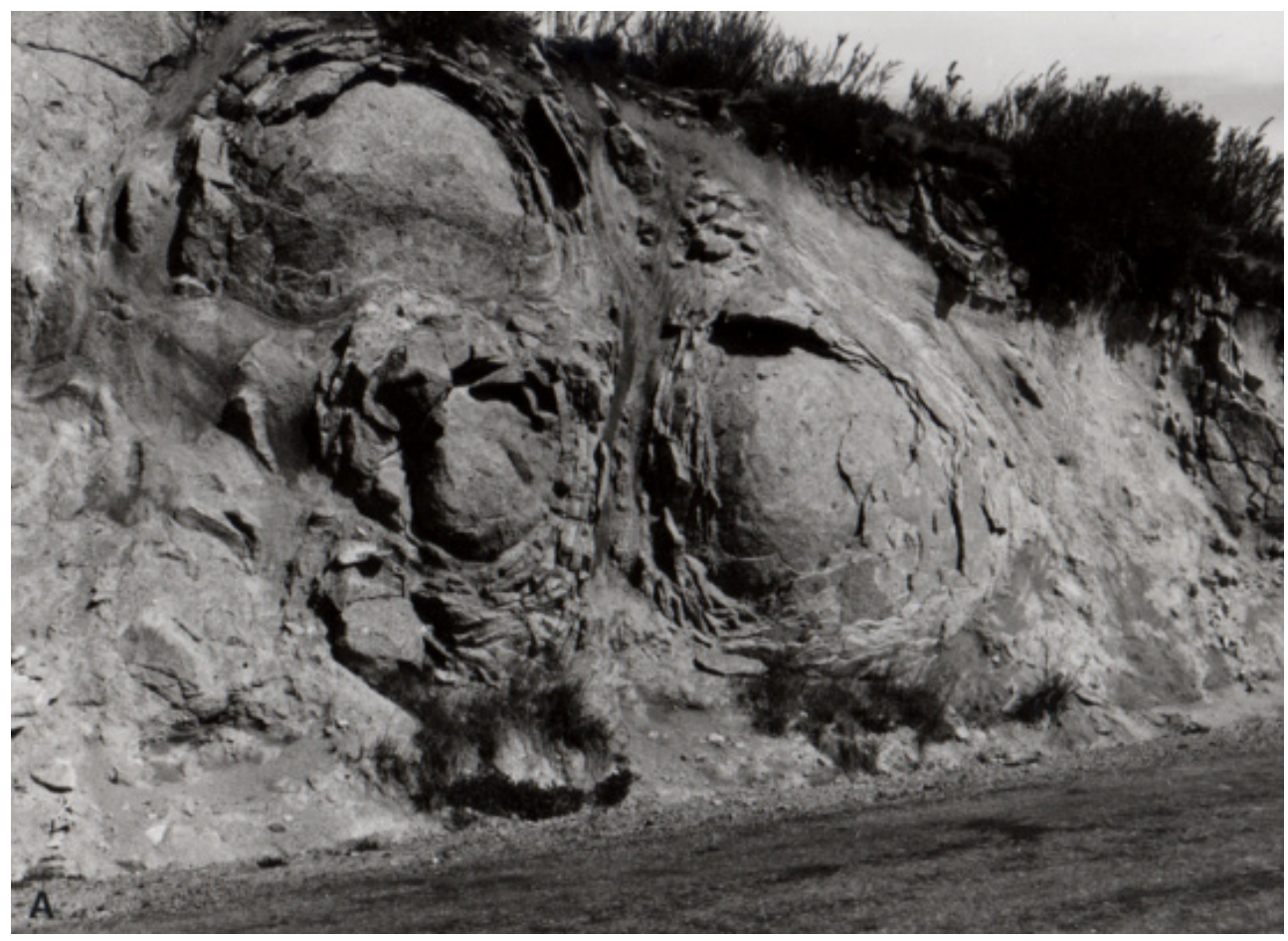

Figure 8. Boulders on the main Palmer Granite outcrop.

The main Adelaide-Mannum road crosses the northern part of the exposure. Two quarries have been excavated in outcrops standing high in the local relief and there are several road cuttings in the country rock. The granite exposed in high quarries is well jointed and many of these blocks display corestones, but with no significant alteration. By contrast granite corestones set in a matrix of laminated but coherent rock are exposed in road cuttings at circa 290 metres. Poorly defined corestones set in grus are exposed in a lower quarry located at $220 \mathrm{~m}$ elevation and in the Palmer town quarry admittedly in the fault and scarp foot zone) all of rotten kaolinitic rock is exposed, though with a surface stony layer.
In summary, in the Palmer area, the granite is well fractured and is divided into quadrangular blocks. In some instances, the corners of the blocks in the form of tetrahedra with concave inner faces, have been sheared and separated from barrel-shaped corestones (Twidale; 1971, pp. 37-38). By contrast, the spherical corestones exposed in the road cuttings, which are located about half way between the local high point and the valley floor to the north and also the section exposed in a lower quarry, are set in either laminated rock or in a granular grussy matrix. In both instances alteration is minimal, and the initial weathering is as much physical as chemical, though it was contact with circulating groundwaters that trans- 
formed the micas and feldspars into swelling hydrophilic clays, resulting in the physical breakdown of the granite.

Though widely and well represented in granitic rocks, corestones are, and as reported, also found in other rock types. Some pose problems. They are, for instance, well developed in the Jurassic basalts of southem Africa. Near Rhodes, in the Eastem Cape Province, they are exposed in road cuttings (Figure 9). The corestone size and spacing suggest a relatively high fracture density. The basalts originated in flows up to $40 \mathrm{~m}$ thick and rapid cooling caused the formation of the widespread columnar jointing. It is assumed that, as with the Mesoprote- rozoic dacitic/rhyolitic flows of the Gawler Ranges (Allen et al. 2003), continued shearing caused horizontal splitting of the columns so that at some stage of cooling the outcrops were sheared and subdivided into angular orthogonal blocks that are theoretically ideal for preferential weathering and the formation of rounded corestones. Yet there are few well rounded dacitic corestones at such sites. Rare but clear evidence suggests that some were shaped in environments that prevailed in earlier times (putatively pre later Cretaceous - Twidale et al. 2020) but those blocks exposed to subsurface weathering more recently remain unweathered and angular.

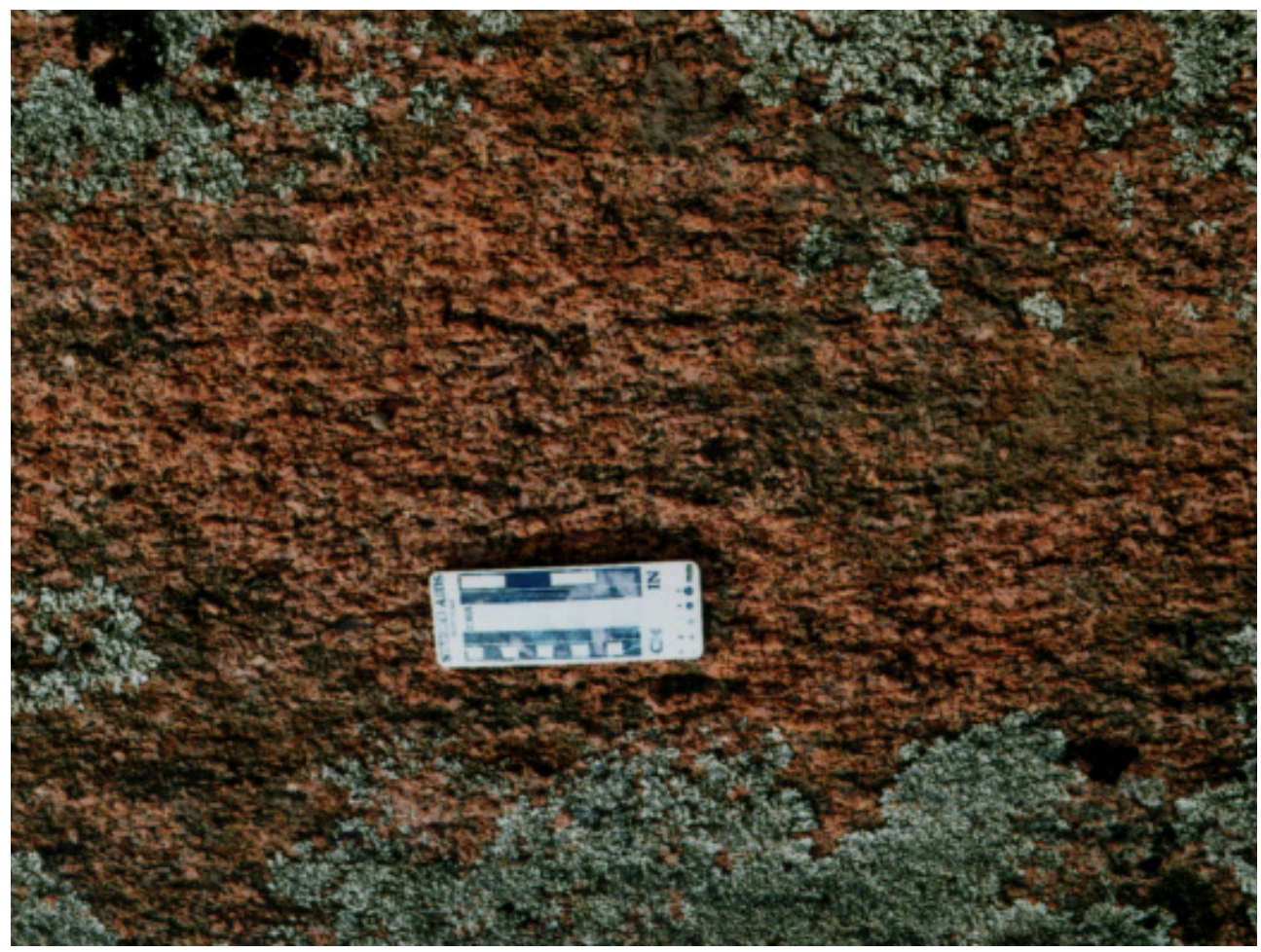

Figure 9. Basalt corestones set in a clay matrix and posed in road cutting near Rhodes, Eastern Cape Province, RSA. 
However, though recently formed corestones are scarce in the Ranges, they are developed in the Mt Cooper inlier of Gawler Range Volcanics located well to the south between Minnipa and Murphy Haystacks, some $50 \mathrm{~km}$ SE of Streaky Bay. This in a higher rainfall area and at site affected by carbonic acid (Figure 10) associated with airborne dust derived for the belt of calcarenitic dunes that border the west coast of Eyre Península (see map in figure 6).

\section{IMPACTS OF CRUSTAL STRESS AND STRAIN}

Clearly, location with regard to water table is an important factor in determining the course of weathering, but a different factor is introduced by the formation of barrel-shaped cores of fresh rock and associated tetrahedral comers in the well-drained rocks exposed in quarries situated high in the local relief.

\section{CORNERSTONES.}

Given the subdivision of a granitic body into cubic or quadrangular blocks of intrinsically fresh and brittle bedrock, shearing has caused rotation and the breaking away of the cornerstones as noted in the higher Palmer quarries. Large cornerstones have been noted also on large residual boulders at Richardson Rocks, 17 km south of Coonalpyn (Twidale and Boume, 1976). And several other sites in the South East district of South Australia - Figures 11) where Early Paleozoic granitic inliers protrude through a field of Pleistocene calcarenitic coastal foredunes (Cook et al., 1977). More weathered and presumably older cornerstones are preserved at Murphy Haystacks, some $40 \mathrm{~km}$ south of Streaky Bay, on north western Eyre Peninsula (Figure $11 \mathrm{a}$ and b; Twidale and Campbell, 1984). 


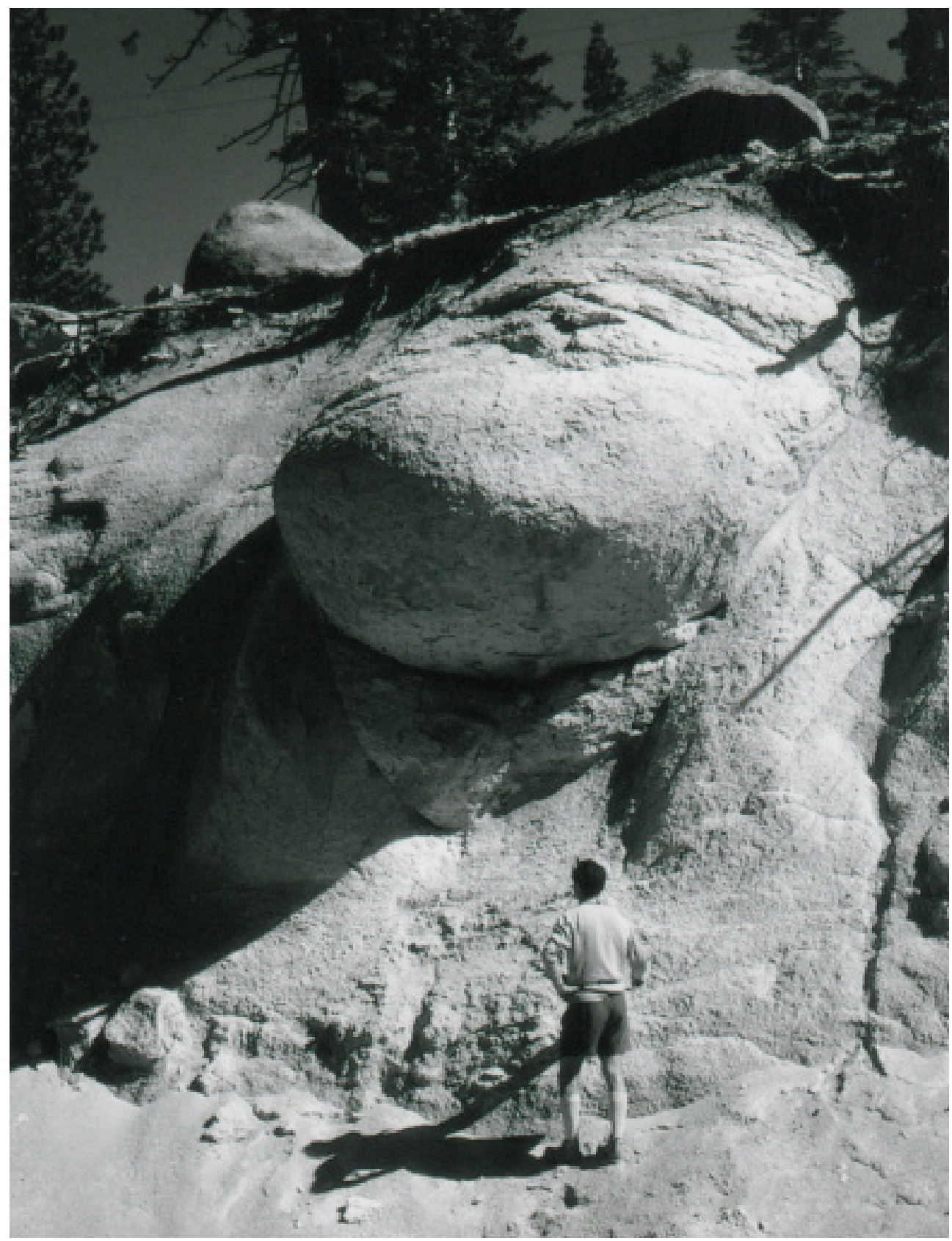

Figure 10, Part of Mt Cooper quarry, western Eyre Peninsula, showing kaolinitic regolith. Note rude corestones in kaolinized country rock. 


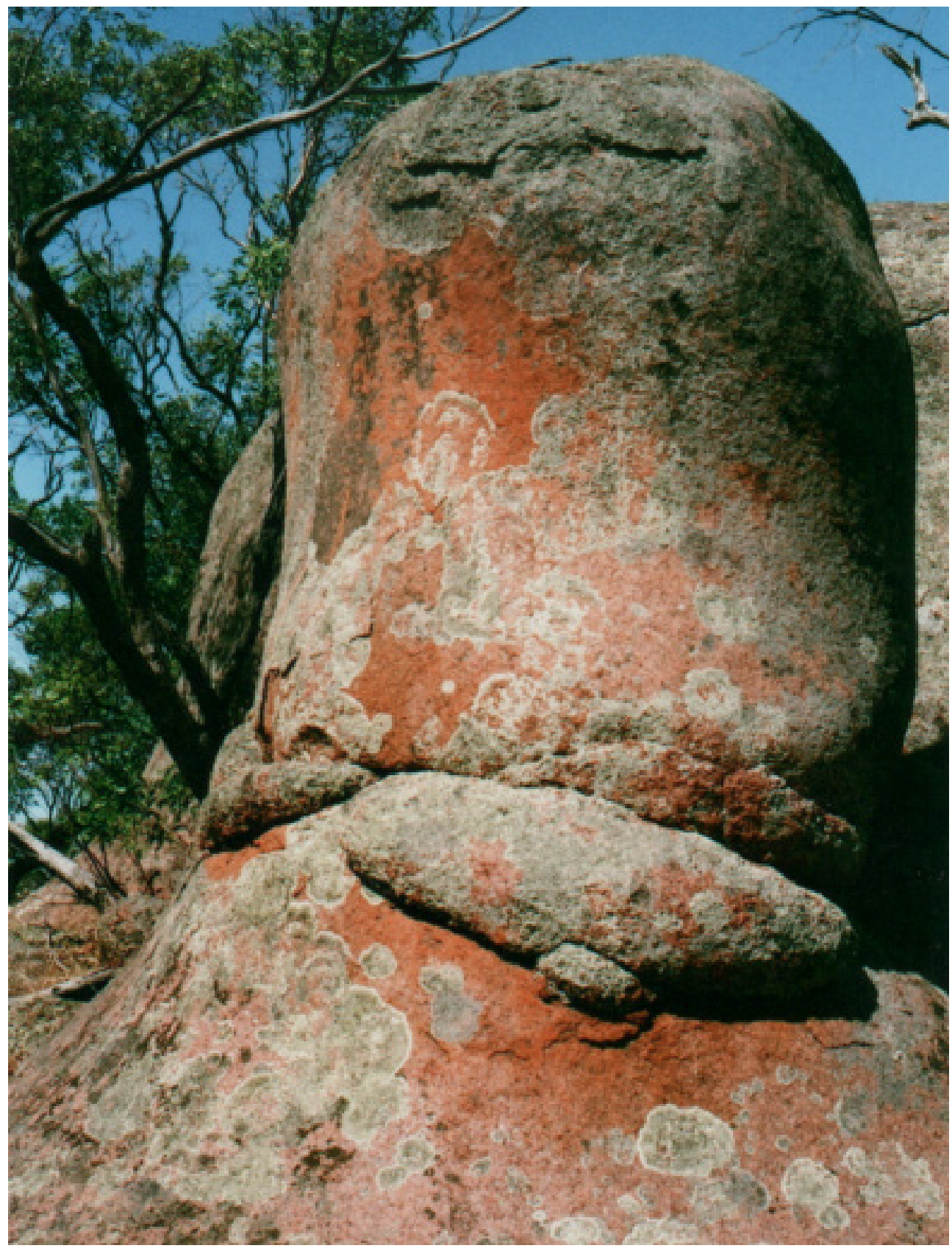

Figure 11. (a) Complex or multistage tetrahedral comer stone developed on large granite boulder, Richardson Rocks, c 20 km SW of Coonalpyn, South East district of South Australia (photo J.A; Bourne). 


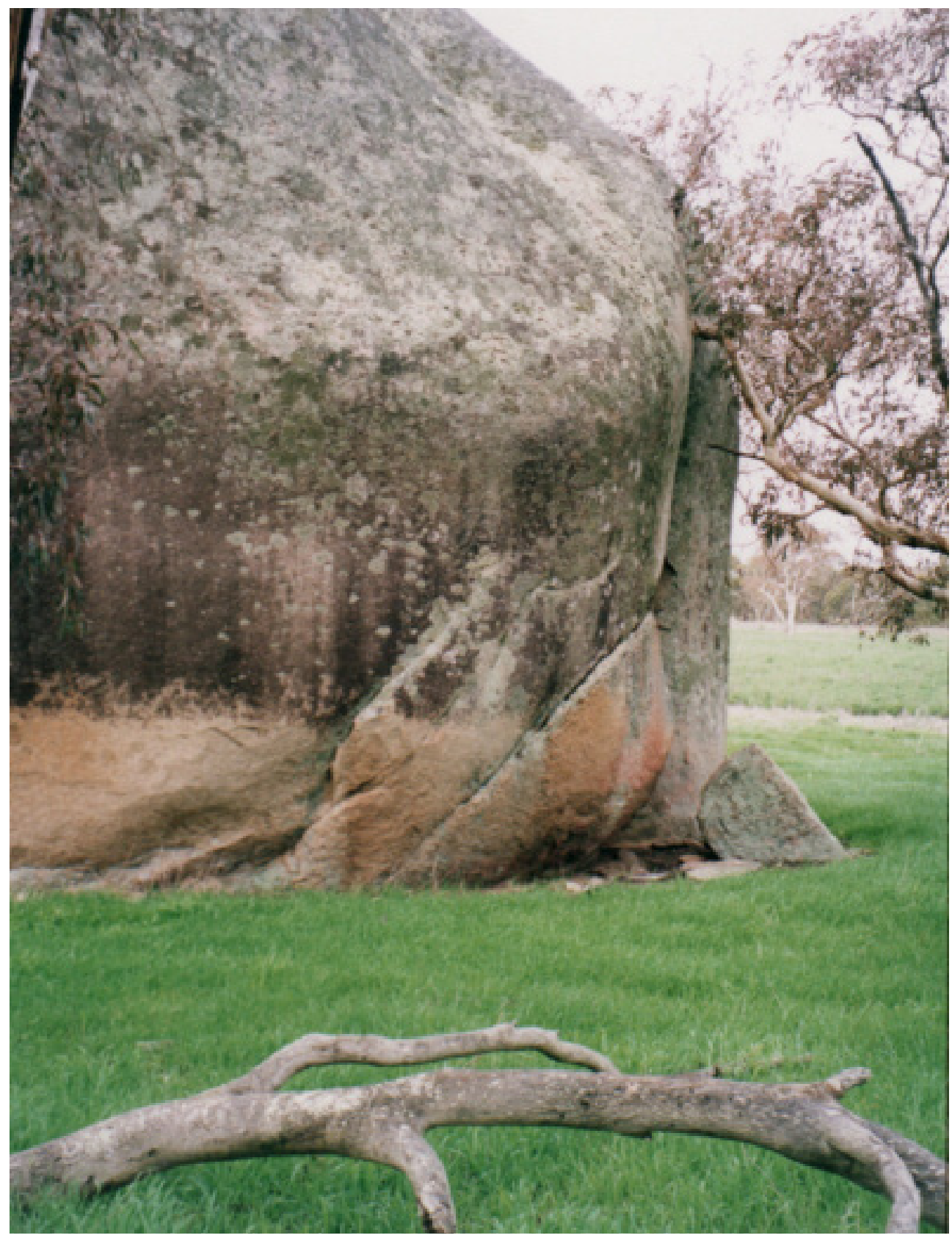

Figure 11. (b) Cornerstone on one of the low towers or turrets that constitute 'Murphy Haystacks', west coast of Eyre Península. 
Several workers have noted that microfissures situated in the marginal zones of blocks and attributable to shearing could have paved the way for weathering (e,g, Birot 1950; Duffaut 1957; Leith et al. 2014). In passing it is interesting to note that the quarrying of Elkington Rock, located some $11 \mathrm{~km}$ NNE of Minnipa, and intended to produce granitic 'Dimension Stone' (strange name!) for use as kitchen counters and ta- ble tops, was abandoned when it was found that the country rock was too fissured and reheating and recrystallisation uneconomic. Similarly, on Pygery Rock and Yarwondutta Rock for example zones of laminated rock up to $2 \mathrm{~m}$ wide have developed in parallel with major fractures (Figure $12 \mathrm{a}$ and $\mathrm{b}$ ), As they are found adjacent to major fractures it is suggested they are shear bands that has facilitated water penetration and lamination.

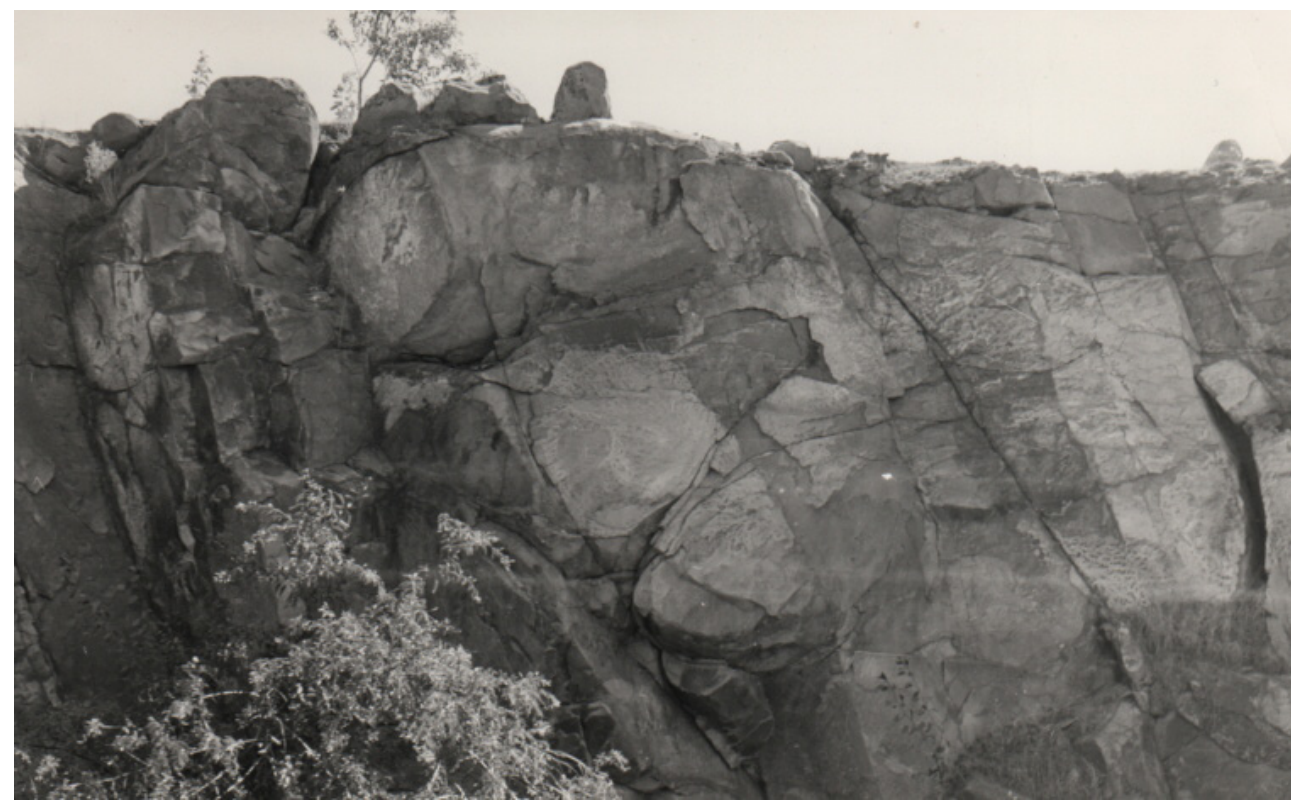

Figure 12. (a) Vertical zone of slivers of laminated granite adjacent to majar fractu re, Pygery Rocks, $7 \mathrm{~km}$ north of Wudinna. 


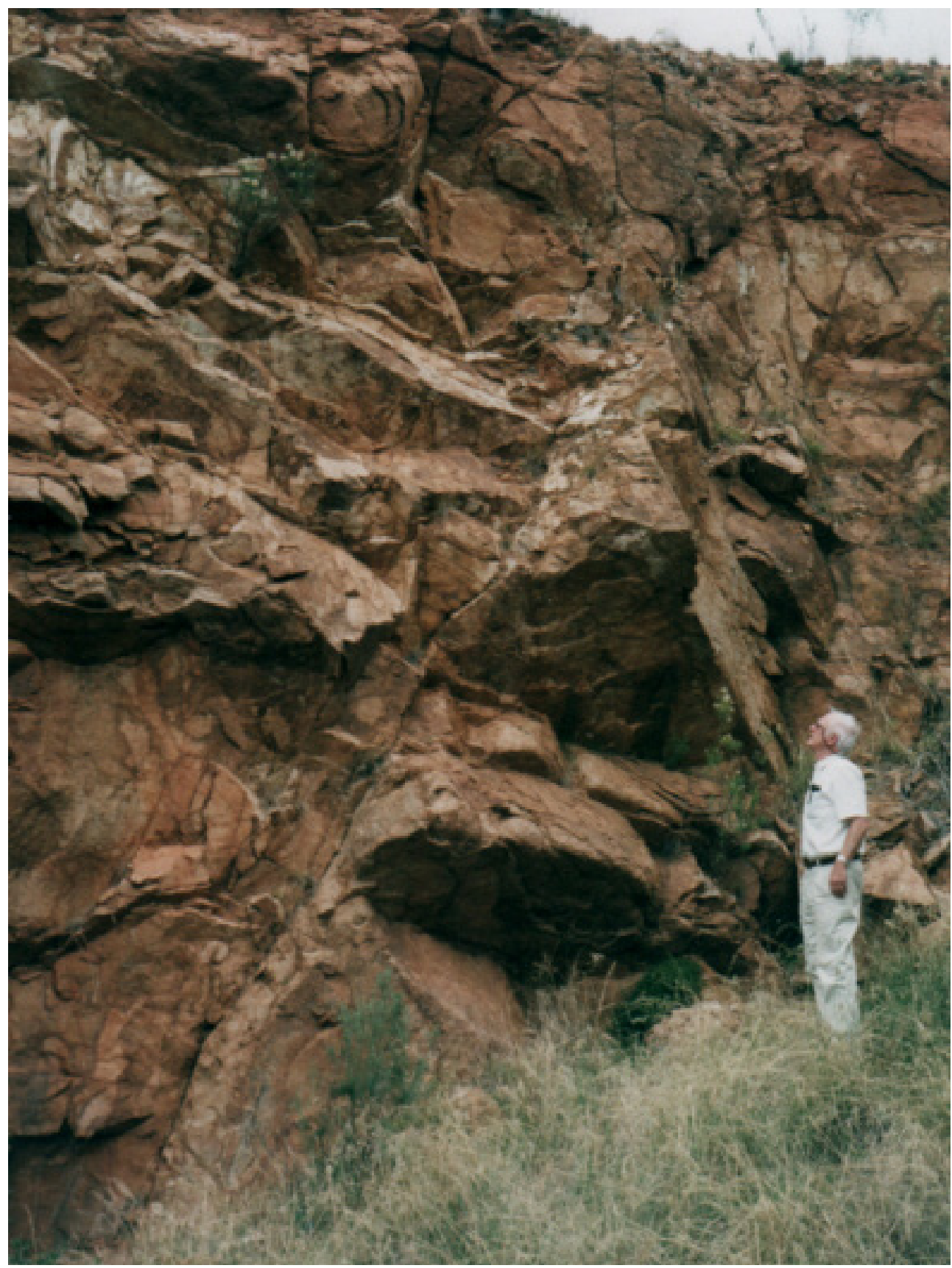

Figure 12. (b) Detail of laminated zone. 


\section{ARCUATE PLATES.}

Sorne corestones are surrounded by more or less thick concentric shells or plates of fresh granodiorite and isolated cornerstones (Figure 13a). As the plates are essentially fresh they can reasonably be construed as due to shearing. In the Snowy Mountains of south eastern New South Wales, and in particular in road cuttings near the Tooma Dam, similar features are developed in granodiorite set in a matrix characterised by well-developed mineral bands (feldspar and ferromagnesium minerals) (Figure 13b).

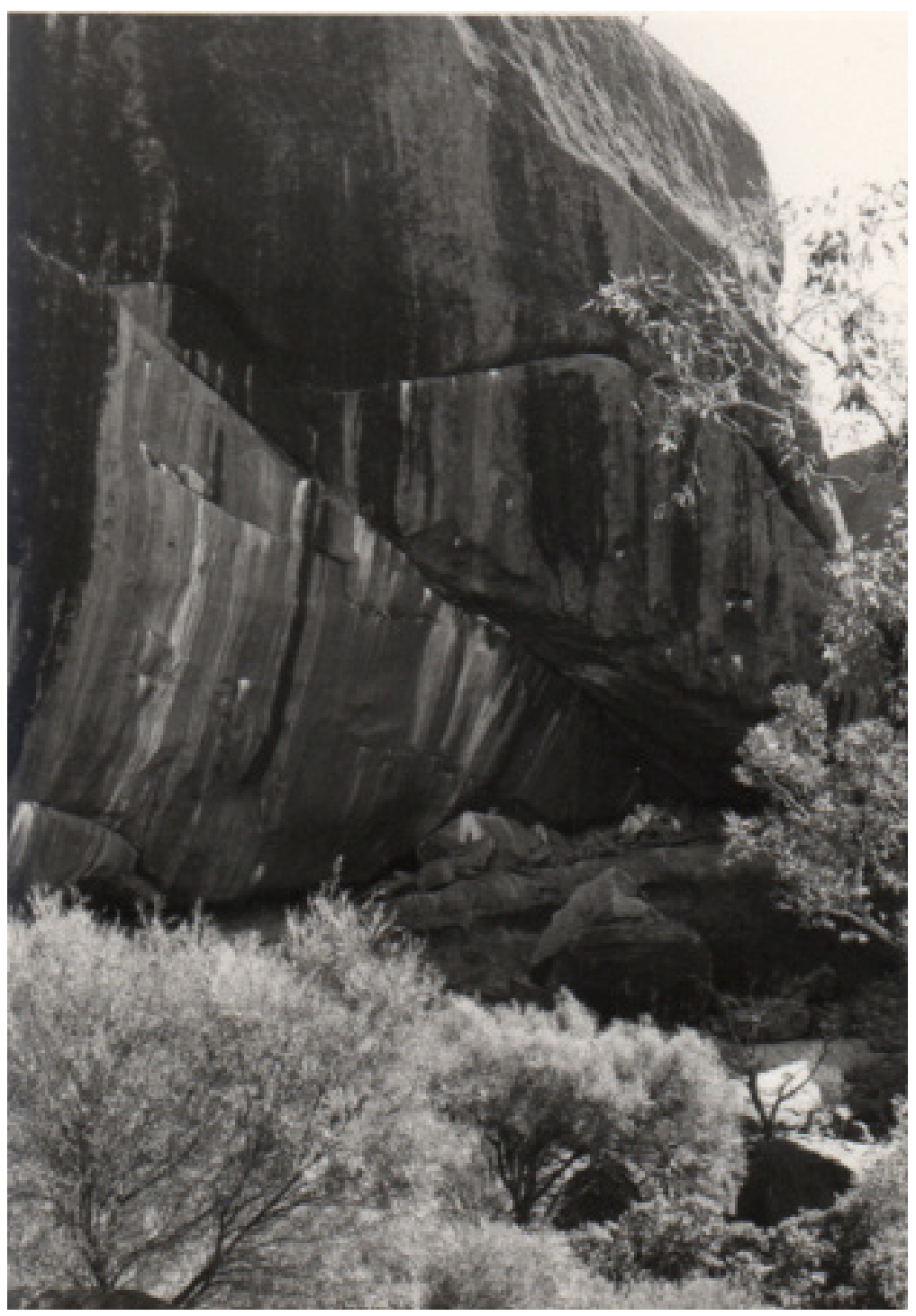




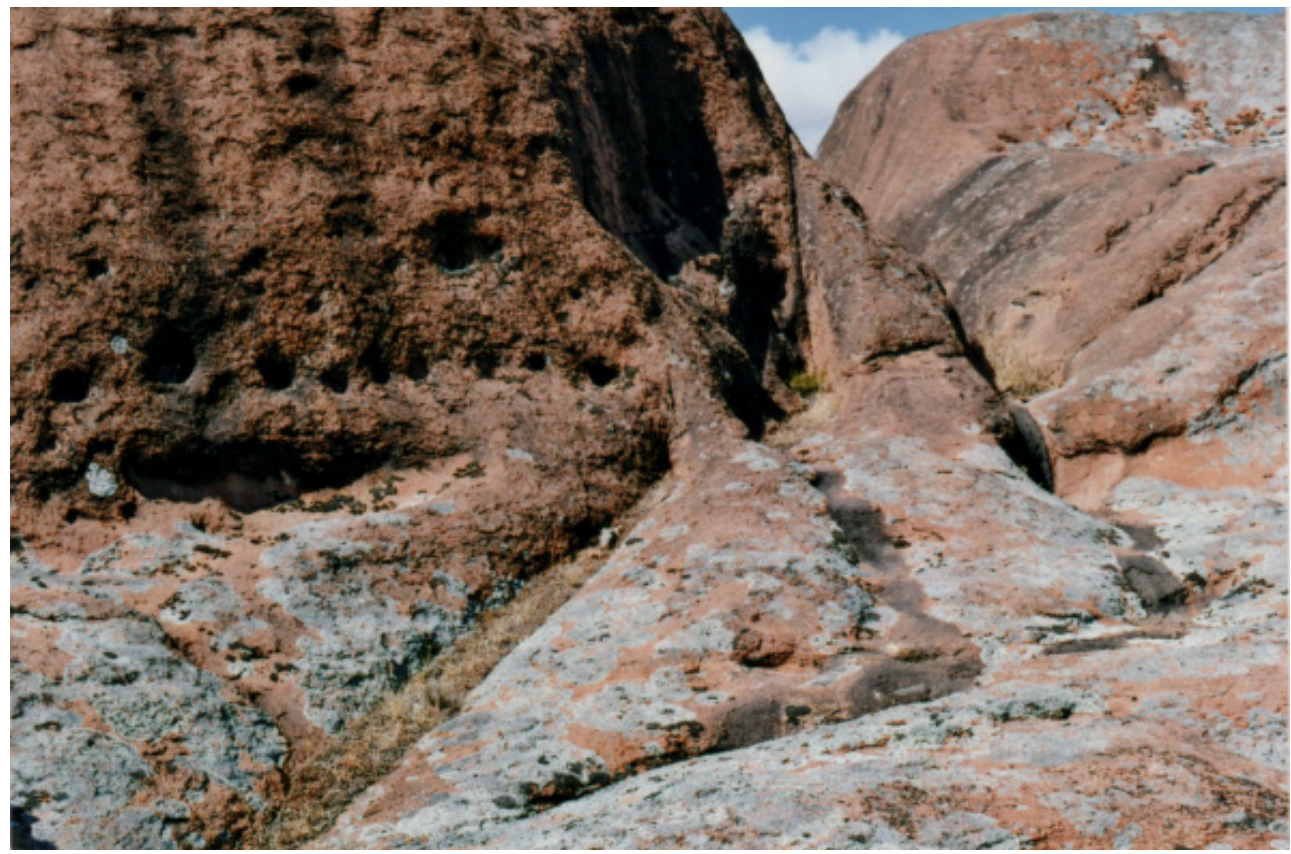

Figure 13. (a) Road cutting near Tooma Dam, Snowy Mountains, south eastern New South Wales, showing corestones in fresh granodiorite with arcuate plates and cornerstones (x) of virtually fresh granodioritc. (b.) Granodioritic corestones and concentric arcuate plates ali set in a matrix of mineralogically banded rock, and exposed in road cutting near Tooma Dam, Snowy Mountains, Ncw South Wales

The banding not only parallels corestones but also patches of fragmented rock. It may be associated with a primary petrogenic cool- ing phase. The spheroidal features are enigmatic and not appear to be associated with subsequent shear (Figures $14 \mathrm{a}$ and $\mathrm{b}$ ) 


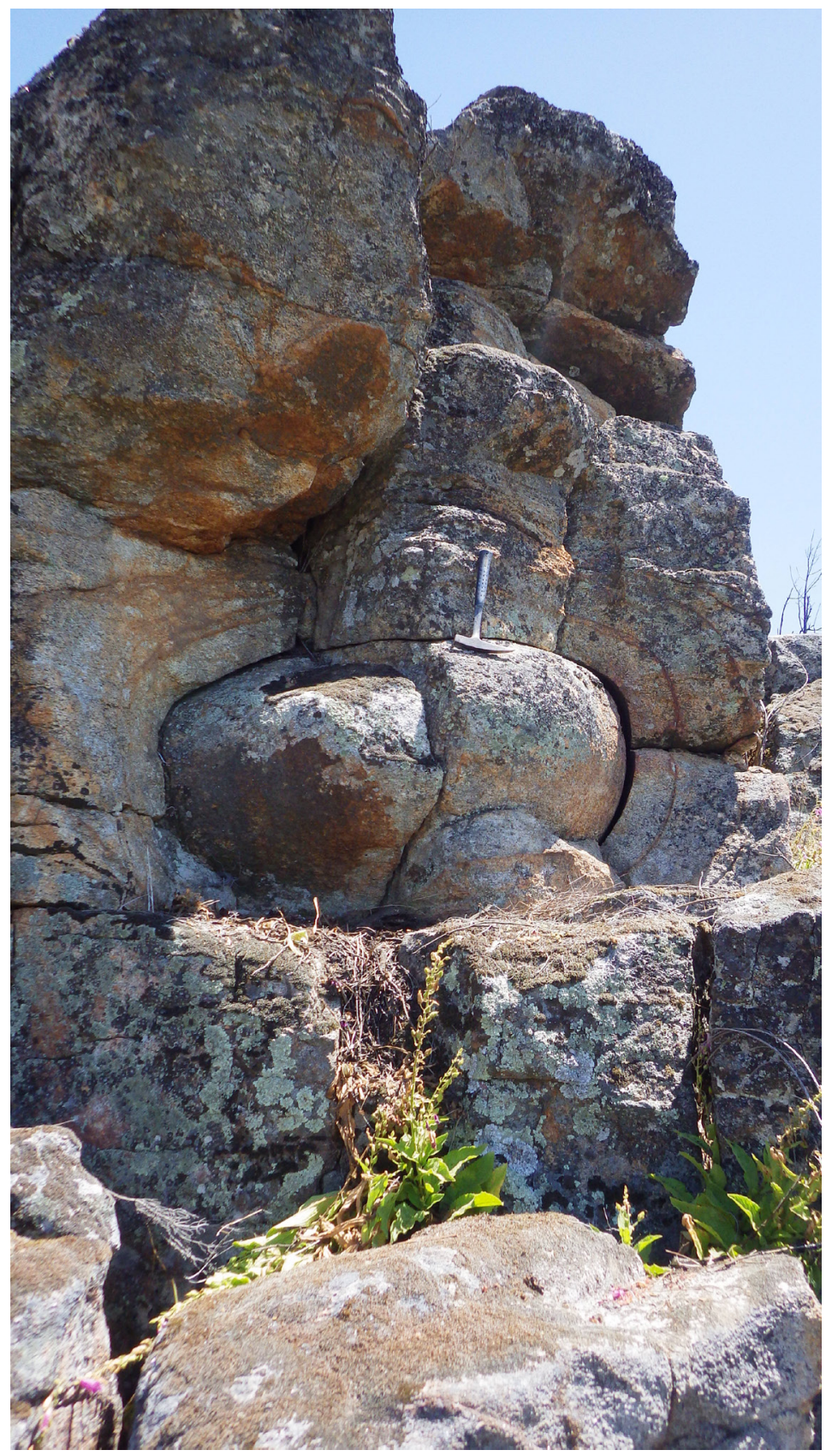

Figure 14. (a) Spheroidal features enigmatic and not appear to be associated with subsequent shear exposed at a site near Valverde, Valpaços Northern Portugal. 


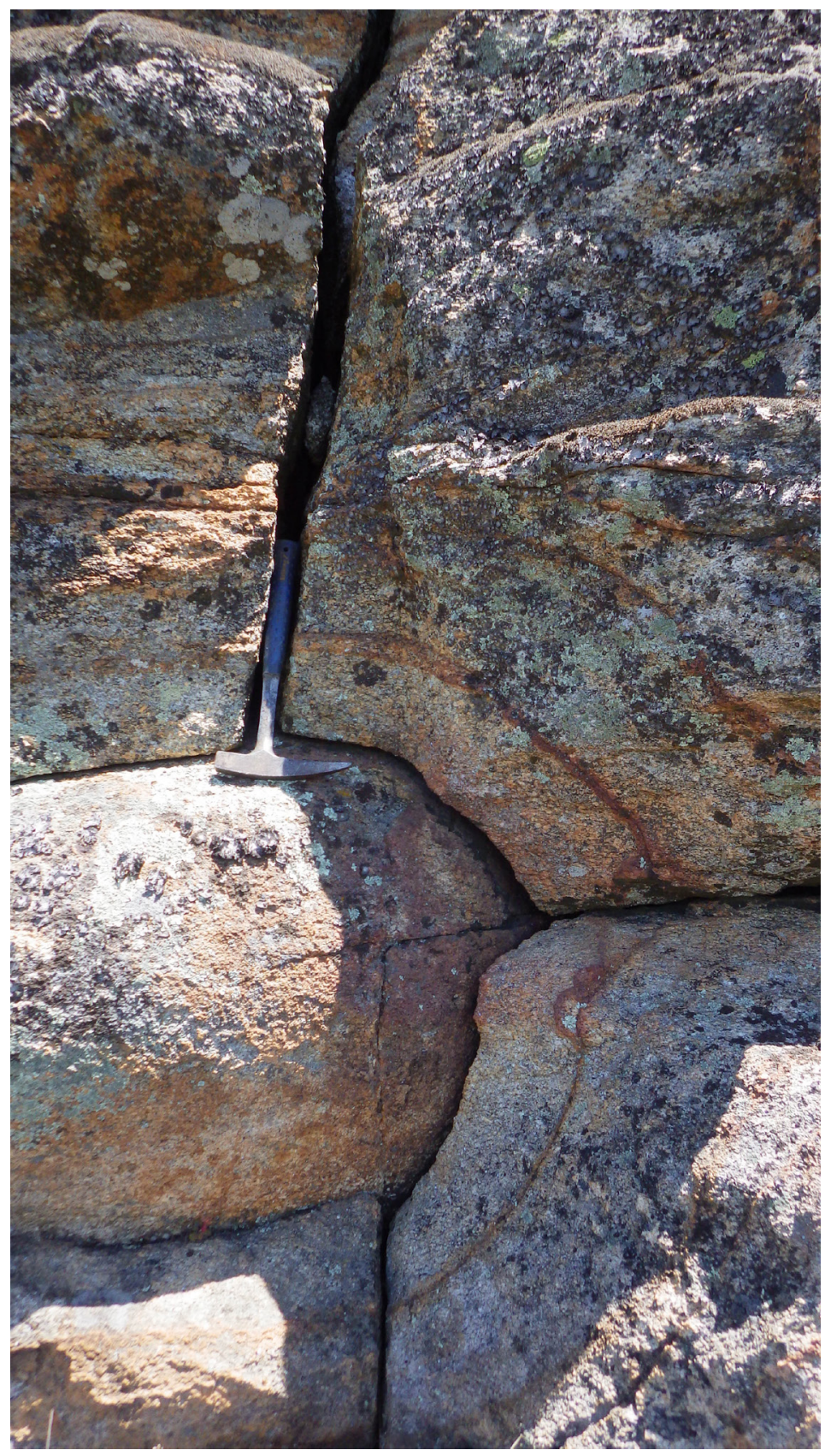

Figure 14. (b) Details of the spheroidal rock; the hammer placed immediately below the central rounded structure can be seen also in Figure 14a. 


\section{EFFECT OF STRESS AND STRAIN.}

Dislocation may have initiated the fractures that define the concentric spall plates, and in addition caused strain in marginal zones of blocks. Though preferential marginal weathering accounts for most corestones, their development would be facilitated and enhanced by any condition such as fissuring, that allows readier water penetration of the rock mass. Also, weakening of bonding in some of the quartz molecules renders such rocks more susceptible to water penetration and dissolution. These observations suggest that zones of strain frequently accompany rupture. The lattices of quartz crystals are disturbed, rendering them especially susceptible to water penetration and alteration (Russell 1935; Turner and Verhoogen 1960, p. 456; Nabarro 1967, p .4) a vulnerability which is obviously further enhanced by the multiple parallel partings developed in some cornerstones. Strain has been called upon to explain the relationship between two clefts or Karren located on the north eastern midslope of Little Wudinna Hill (Twidale 1993). One cleft is located along a fracture zone. A few metres away and downslope is another cleft, parallel to the first, but less perfectly linear. Short lengths of fracture are visible and then longer axes of laths of feldspar stand in approximate parallelism with the cleft (this by contrast with their random alignment in the main mass of the country rock). It is suggested that the same stresses that caused the perfect Klufikarren are responsible for the second 'strain cleft' but fell short of causing rupture. Indeed, it can be argued that the formation of the fracture at the first site relieved stress in adjacent areas such that the lower area was left in strain, the stage prior to rupture.
Extrapolation of this suggestion of strain finding structural and morphological expression is germane to the understanding of cornerstone and arcuate spall plates, for continued shearing could impose not only the separation of tetrahedral corners but also of arcuate fractures wrapped around the compressed cores as illustrated earlier. Similar but larger scale wedges have developed on sheet fractures, confirming that the latter are planes of dislocation and that lateral wedges are tectonic in origin.

\section{DISCUSSION AND CONCLUSIONS}

The shearing of granitic massifs has contributed, albeit in most instances in a relatively small way, to the rounding of blocks and their transformation to boulders. It may be responsible for the shells developed around some corestones for the rocks involved are essentially fresh. It also suggests the possibility that the preferential marginal weathering to which many corestones are rightly attributed could have been facilitated by strain or the formation of fissures and fractures in the corners of the affected blocks from which are derived floaters and eventually corestone boulders. Finally, it is noted that at some sites cornerstones are developed on a much larger scale than those discussed in the context of the rounding of corestone boulders. Many, and perhaps most, cornerstones and associated plates are the result either of preferential weathering facilitated by crustal stress and strain or solely by tectonic dislocation.

\section{REFERENCES}

Ackermann, E., 1962. Bussersteine- Zeugen vorzeitlicher Grundwasserschwankun- 
gen. Zeitschrift für Geomorphologie 6, 148-182.

Allen, S.R., Simpson, C.J., Mcphie, J., Daly, S.J., 2003. Stratigraphy, distribution and geochemistry of widespread felsic volcanic units in the Mesoproterozoic Gawler Range Volcanics, South Australia. Australian Journal of Earth Sciences 50, 97-112.

Beche H.T. de la, 1839. Report on the Geology of Cornwall, Devon and West Somerset (Geological Survey of England and Wales). Longman, Orme, Brown, Green and Longmans, London, $648 \mathrm{pp}$.

Beche, H.T. de la, 1853. The Geological Observer. Longmans, Brown, Green and Longmans, London, 846 pp.

Belperio, A.P., 1995. Quaternary. Introduction. In: Drexel, J.F., Preiss, W.V. (Eds.), The geology of South Australia. Volume 2. The Phanerozoic. Geological Survey of South Australia Bulletin 54, 222-224.

Birot P., 1950. Notes sur le probleme de la désagrégation $\mathrm{d}$ es roches cristallines. Revue de Géomorphologie Dynamique 1, 271-276.

Büdel, J., 1957. Die "doppelten Einebnungsflachen" in den feuchten Tropen. Zeitschrijt fiir Geomorphologie 1, 201208.

Cook, P.J., Colwell, J.B., Firman, J.B., Lindsay, J.M., Schwebel, D.A., Von Der Borch, C.C. 1977. The late Cainozoic sequence of southeast South Australia and Pleistocene sea level changes. Bureau of Mineral Resources Journal of Australian Geology \& Geophysics 2, 81-88.

Duffaut, P., 1957. Sur la genese des 'boules' de certains granites. Comptes Rendus et Sommaire. Bulletin. Societe Géologique de France 7, 139-141.
Eggler D.H., Larsen E.E., Bradley W.C., 1969. Granites, grusses and the Sherman erosion surface, southern Laramie Range, Colorado-Wyoming. American Journal of Science 267, 510-522.

Hassenfratz, J-H., 1791. Sur l'arrangement de plusieurs gros blocs de différentes pierres que l'on observe dans les montagnes. Annales de Chimie 11, 95-107.

Hutton, J., 1788. Theory of the Earth; or an investigation of the laws observable in the composition, dissolution and restoration of land upon the globe. Transactions of the Royal Society of Edinburgh 1, 209-304.

Hutton, J.T., Lindsay D.S., Twidale C.R., 1977. The weathering of norite at Black Hill, South Australia. Journal of the Geological Society of Australia 24, 37-50.

Jones, T.R., 1859. Notes on sorne granite tors. The Geologist, 2, 301-312.

Kingsmill, T.W., 1862. Notes on the geology of the east coast of China. Journal of the Royal Geological Society of Ireland 10, 1-6.

Larsen ES., 1948. Batholith and associated rocks of Corona, Elsinore and San Luis Rey quadrangles, southern California. Geological Society of America Memoir 29, 113-119.

Leith K., Moore J.R., Amann F., Loew S., 2014. In situ stress control on microcrack generation and macroscopic fracture in exhuming bedrock. Journal of Geophysical Research: solid Earth 119, 12-22. https://doi.org/10.1002/2012JB009801

Logan J.R., 1849. The rocks of Pulo Ubin, with sorne remarks on the formation and structure of hypogene rocks and on the metamorphic theory. Verhandlungen Genootschap van Kunsten en Wetenschappen (Batavia) 22, 3-43 
Logan, J.R., 1851. Notes on the geology of the straits of Singapore. Quarterly Journal of the Geological Society of London 7, 310-344.

Loughnan, F.C., 1969. Chemical Weathering of the Silicate Minerals. Elsevier, New York, 154 pp.

Mabbutt, J.A., 1961. 'Basal surface' or 'weathering front'. Proceedings of the Geologists' Association of London 72, 357-358.

Macculloch, J., 1814. On the granite tors of Cornwall. Transactions of the Geological Society 2, 66-78.

Milnes A.R., Ludbrook N.H. 1986. Provenance of microfossils in aeolian calcarenites and calcretes in southern South Australia. Australian Journal of Earth Sciences 33, 145-159.

Nabarro, F.R.N., 1967. Theory of Crystal Dislocations. Clarendon Press, Oxford, $821 \mathrm{p}$.

Russell, G.A., 1935. Crystal growth and solution under local stress. American Mineralogist 20, 733-737.

Scrivenor, J.B., 1913. Geology of Malaya. Quarterly Journal of the Geological Society of London 69, 343-369.

Turner, F.J., Verhoogen, J., 1960. Igneous and Metamorphic Petrology. McGrawHill. New York. 694 pp.

Twidale, C.R., 1971. Structural Landforms. Australian National University Press, Canberra, 247 p.
Twidale, C.R., 1986. Granite landform evolution: factors and implications. Geologische Rundschau 75, 769-779

Twidale, C.R., 1993. The research frontier and beyond: granitic terrains, pp. 187223 in J.D. Vitek \& J.R. Giardino, (editors) Special Issue, Geomorphology: The Research Frontier and Beyond 7 (1$3)$. Proceedings of the 24th Binghamton Symposium in Geomorphology, $25 \mathrm{Au}-$ gust 1993. Elsevier, Amsterdam, 265 pp.

Twidale, C.R., Bourne, J.A., 1976. The shaping and interpretation of large residual granite boulders. Journal of the Geological Society of Australia 23, 371-381

Twidale C.R., Campbell E.M., 1984. Murphy Haystacks, Eyre Peninsula, South Australia. Transactions of the Royal Society of South Australia 108 (3), 175183.

Twidale C.R., Campbell E.M., Bourne J.A., 2020. Evolution of an ancient cratonic upland, the Gawler Ranges of inland South Australia, Géomorphologie: relief, processus, environnement, 26 (1), 35-54. https://doi.org/10.4000/geomorphologie. 14036

Wilson, C.C., 1991. Geology of the Quaternary Bridgewater Formation of southwest and central South Australia [Ph.D. thesis]: Adelaide, Flinders University of South Australia. 341 pp. 